\title{
Laboratory Study for the Reduction of Chrome(VI) to Chrome(III) Using Sodium Metabisulfite under Acidic Conditions
}

\section{J. B. Duncan et al.}

CH2M HILL Hanford Group, Inc.

Richland, WA 99352

U.S. Department of Energy Contract DE-AC27-99RL14047

\author{
EDT/ECN: DRF UC: \\ Cost Center: 7S110 Charge Code: \\ B\&R Code: Total Pages: 29
}

Key Words: hexavalent chromium, trivalent chromium, ETF, TCLP, sodium metabisulfite, sodium hydroxide, chromium hydroxide, inductively coupled plasma-mass spectroscopy, reaction, tap water, $\mathrm{pH}$, sodium sulfate, Liquid Effluent Retention Basin 43

Abstract: This report describes the results from RPP-PLAN-32738, "Test Plan for the Effluent Treatment Facility to Reduce Chrome(VI) to Chrome(III) in the Secondary Waste Stream," using sodium metabisulfite. Appendix A presents the report as submitted by the Center for Laboratory Sciences (CLS) to CH2M HILL Hanford Group, Inc. The CLS carried out the laboratory effort under Contract Number 21065 , release Number 30 . This report extracts the more pertinent aspects of the laboratory effort.

TRADEMARK DISCLAIMER. Reference herein to any specific commercial product, process, or service by trade name, trademark, manufacturer, or otherwise, does not necessarily constitute or imply its endorsement, recommendation, or favoring by the United States Government or any agency thereof or its contractors or subcontractors.

Printed in the United States of America. To obtain copies of this document, contact: Document Control Services, P.O. Box 950, Mailstop H6-08, Richland WA 99352, Phone (509) 372-2420; Fax (509) 376-4989.

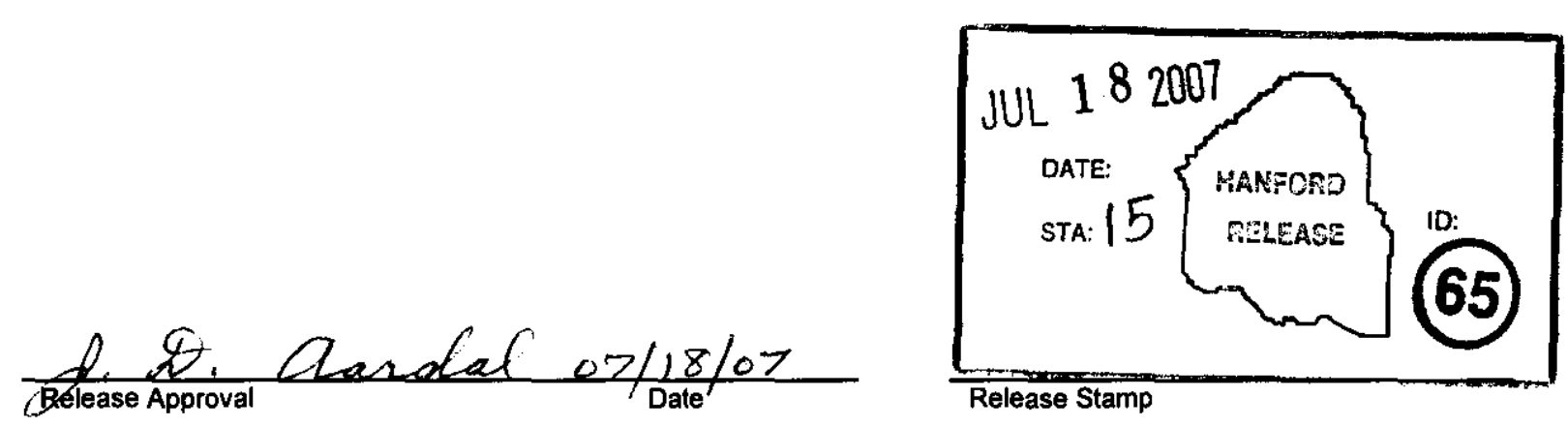

Approved For Public Release 


\title{
LABORATORY STUDY FOR THE REDUCTION OF CHROME(VI) TO CHROME(III) USING SODIUM METABISULFITE UNDER ACIDIC CONDITIONS
}

\author{
J. B. Duncan \\ CH2M HILL Hanford Group, Inc.
}

M. D. Guthrie

Fluor Hanford

K. J. Lueck

Fluor Hanford

M. Avila

RJ Lee Group

Date Published

July 2007

\section{CH2NHILL \\ Hanford Group, Inc.}

Prepared for the U.S. Department of Energy

Office of River Protection

Contract No. DE-AC27-99RL14047 


\section{Table of Contents}

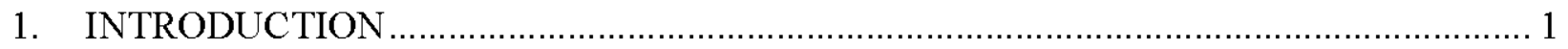

2. PROCEDURE AND RESULTS …......................................................................... 2

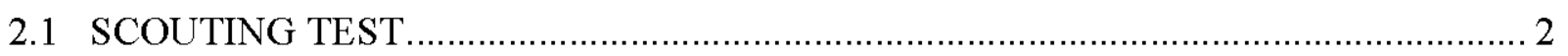

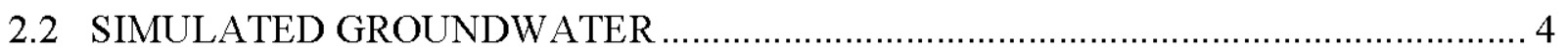

2.2 TOXICITY CHARACTERISTIC LEACHING PROCEDURE RESULTS .................... 6

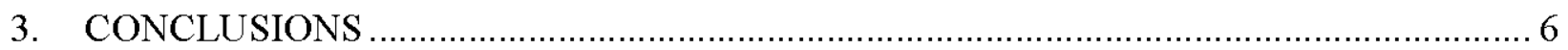

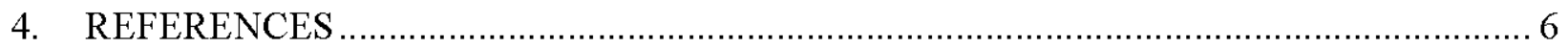

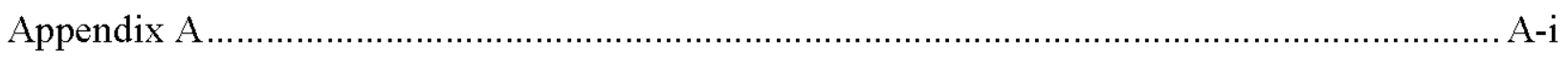

\section{List of Figures}

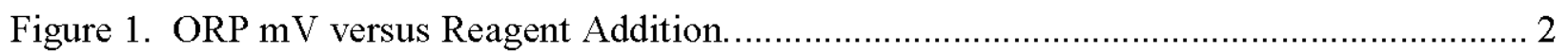

Figure 2. Cumulative Volume of $0.5 \mathrm{M}$ Sodium Metabisulfite to Achieve an Oxidation Reduction Potential of 279 at pH 2 in $20 \mathrm{Wt} \%$ Sodium Sulfate and $80 \mathrm{mg} / \mathrm{L} \mathrm{Cr}$ (VI)... 3

Figure 3. Cumulative Volume of $10 \mathrm{~N}$ Sodium Hydroxide to Achieve a pH Greater than 10.5... 3

Figure 4. Cumulative Volume of $0.5 \mathrm{M}$ Sodium Metabisulfite to Achieve an ORP of 280

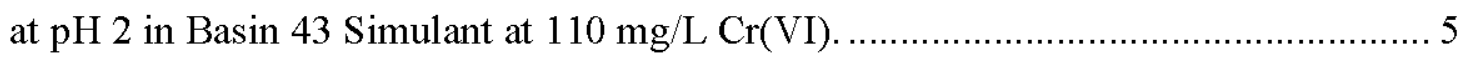

Figure 5. Cumulative Volume of $10 \mathrm{~N}$ Sodium Hydroxide to Achieve a pH Greater than 10.5...5

\section{List of Tables}

Table 1. Liquid Effluent Retention Facility Basin 43 Groundwater Simulant. ........................ 4

Table 2. Toxicity Characteristic Leaching Procedure Results.............................................. 6 


\section{INTRODUCTION}

This report describes the results from RPP-PLAN-32738, Test Plan for the Effluent Treatment Facility to Reduce Chrome(VI) to Chrome(III) in the Secondary Waste Stream, using sodium metabisulfite. Appendix A presents the report as submitted by the Center for Laboratory Sciences (CLS) to CH2M HILL Hanford Group, Inc. The CLS carried out the laboratory effort under Contract Number 21065, release Number 30. This report extracts the more pertinent aspects of the laboratory effort.

The reduction of hexavalent chromium [Cr(VI)] to trivalent chromium [Cr(III)] will decrease the mobility of chromium in the environment, allowing the waste stream from the Effluent Treatment Facility (ETF) Thin Film Dryer to pass the Method 1311, "Toxicity Characteristic Leaching Procedure" (TCLP), for final disposal in the Environmental Restoration Disposal Facility landfill.

The effort used sodium metabisulfite as the reducing agent. Sodium metabisulfite, when added to water, forms sodium bisulfite (Equation 1). In the presence of acid and $\mathrm{Cr}(\mathrm{VI})$, the sodium bisulfite has the following reaction as shown in Equations 2 and 3 (Pollution Prevention and Control Technology for Plating Operations, Cushnie 1994):

$$
\mathrm{Na}_{2} \mathrm{~S}_{2} \mathrm{O}_{5}+\mathrm{H}_{2} \mathrm{O} \rightarrow 2 \mathrm{NaHSO}_{3}
$$

Then

$$
3 \mathrm{NaHSO}_{3}+2 \mathrm{H}_{2} \mathrm{CrO}_{4}+3 \mathrm{H}_{2} \mathrm{SO}_{4} \rightarrow \mathrm{Cr}_{2}\left(\mathrm{SO}_{4}\right)_{3}+5 \mathrm{H}_{2} \mathrm{O}+3 \mathrm{NaHSO}_{4}
$$

After the hexavalent chromium is reduced to the trivalent state, it is then reacted with caustic to precipitate chromium hydroxide $\left[\mathrm{Cr}(\mathrm{OH})_{3}\right]$ as shown in Equation 3.

$$
\mathrm{Cr}_{2}\left(\mathrm{SO}_{4}\right)_{3}+3 \mathrm{NaOH} \rightarrow 2 \mathrm{Cr}(\mathrm{OH})_{3}+3 \mathrm{Na}_{2} \mathrm{SO}_{4}
$$

During the course of the experiments, $\mathrm{Cr}$ (VI) and total $\mathrm{Cr}$ were determined using ion chromatography and inductively coupled plasma-mass spectroscopy, respectively. Since there is no laboratory method for $\mathrm{Cr}(\mathrm{III})$, the difference between $\mathrm{Cr}(\mathrm{VI})$ and total $\mathrm{Cr}$ is assumed to be $\mathrm{Cr}$ (III) due to the reduction reaction (Equation 2).

The sodium metabisulfite was successful at the lower $\mathrm{pH}$ ranges and at an oxidation reduction potential (ORP) of approximately $+280 \mathrm{mV}$, Figure 1 (ADS 3300-02/rev.A). 
Figure 1. ORP mV versus Reagent Addition.

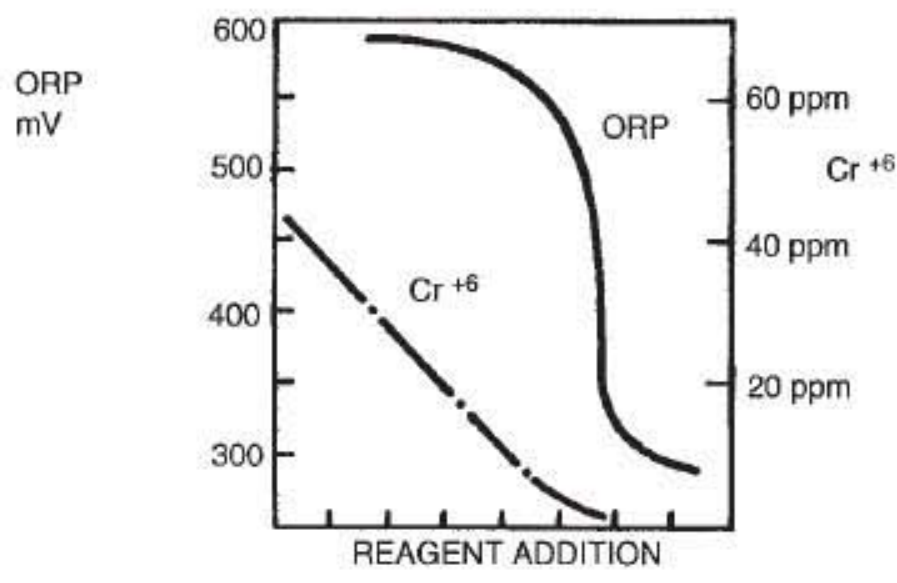

\section{PROCEDURE AND RESULTS}

\section{$2.1 \quad$ SCOUTINGTEST}

To test the efficacy of $\mathrm{Cr}$ (VI) reduction using sodium metabisulfite, a solution of $100 \mathrm{ppm}$ sodium chromate was formulated in tap water containing $20 \mathrm{wt} \%$ of sodium sulfate. Two levels of $\mathrm{pH}$ were tested, $\mathrm{pH} 2$ and $\mathrm{pH} 4$. As will be shown, the $\mathrm{pH} 4$ solution was not as efficacious as was the more acidic solution.

A scouting test was performed at $\mathrm{pH} 2$ using tap water, $20 \mathrm{wt} \%$ sodium sulfate, and a calculated (unconfirmed) concentration of $\mathrm{Cr}$ (VI), reported as Table 1 and 2 in Appendix A. Table 3 of Appendix $\mathrm{A}$ indicates the amount of sodium hydroxide used to raise the $\mathrm{pH}$ to greater than 10.5 .

The tests were considered successful and a second experiment was conducted using the same conditions. The tabular results are presented in Tables 4 and 5 of Appendix A. Figure 2 shows the cumulative milliliters used to adjust the solution to an ORP value of 279 , a total of $13 \mathrm{~mL} / \mathrm{L}$. The $\mathrm{pH}$ was maintained as close to $\mathrm{pH} 2$ by addition of sulfuric acid during the experiment. Figure 3 shows the amount of $10 \mathrm{~N}$ sodium hydroxide per liter consumed to attain a $\mathrm{pH}$ of 10.78 .

Another solution was prepared as above and titrated with sodium metabisulfite at pH 4 (Table 6 in Appendix A). The $\mathrm{Cr}$ (VI) was reduced from $110 \mathrm{mg} / \mathrm{L}$ to $28 \mathrm{mg} / \mathrm{L}$. It was decided not to continue the titration and not pursue the reduction of $\mathrm{Cr}(\mathrm{VI})$ to $\mathrm{Cr}(\mathrm{II})$ in solutions greater than a $\mathrm{pH}$ of 2.

After the sodium metabisulfite titration, the solution $\mathrm{pH}$ was raised to 10.5 or greater to precip itate $\mathrm{Cr}(\mathrm{OH})_{3}$. The solution was then dried at $180^{\circ} \mathrm{C}$ to simulate ETF Thin Film Dryer conditions and a TCLP was performed. The results from the $\mathrm{pH} 2$ solution (Table 8 in Appendix A) are the following:
$\mathrm{pH}$
Total Cr (ppm)
Cr(VI) (ppm)
$2 \rightarrow 10$
0.32575
0.00254 
Figure 2. Cumulative Volume of $0.5 \mathrm{M}$ Sodium Metabisulfite to Achieve an Oxidation Reduction Potential of 279 at pH 2 in $20 \mathrm{Wt} \%$ Sodium Sulfate and $80 \mathrm{mg} / \mathrm{L} \mathrm{Cr}$ (VI).

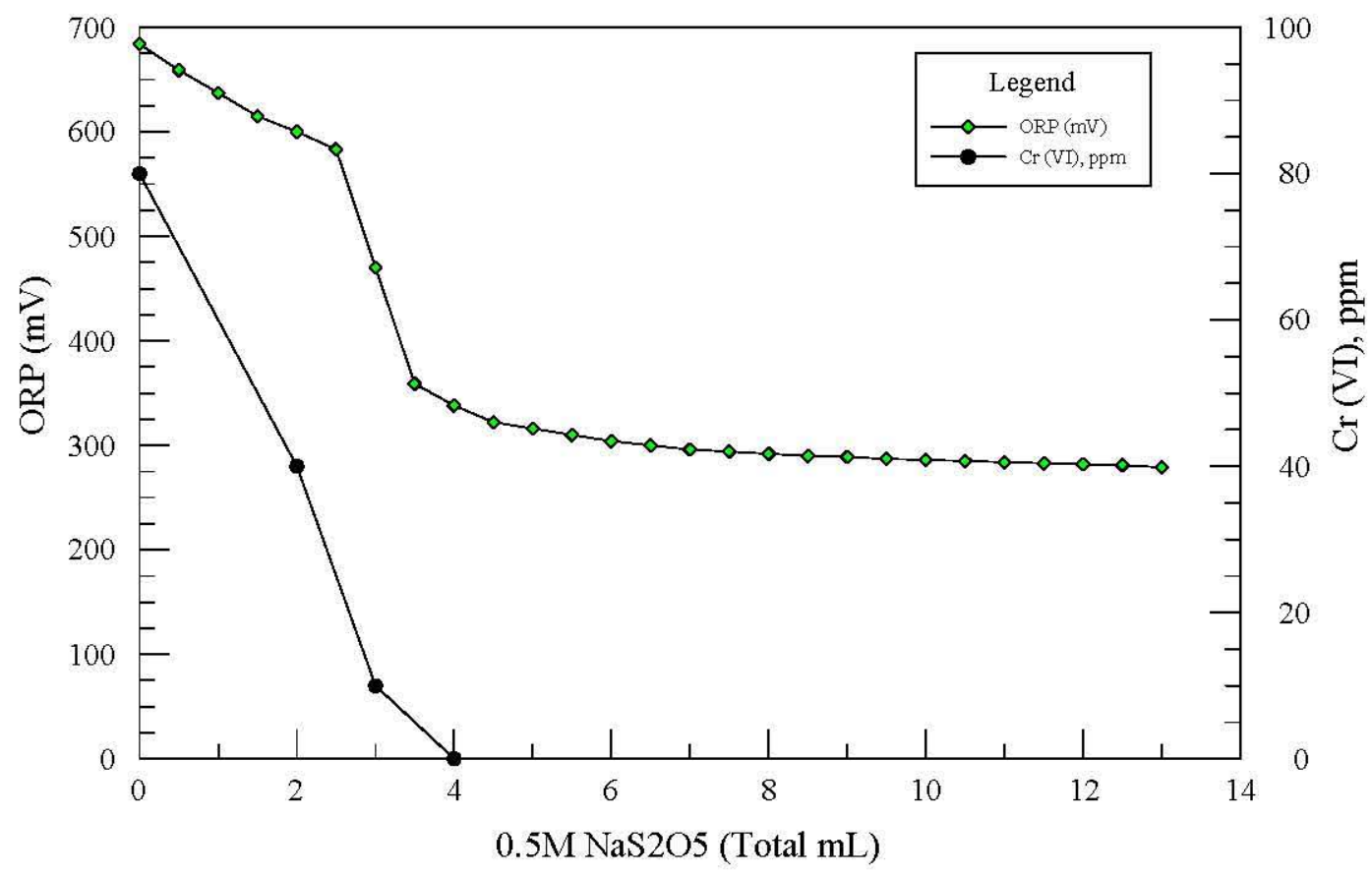

Figure 3. Cumulative Volume of 10N Sodium Hydroxide to Achieve a pH Greater than 10.5 .

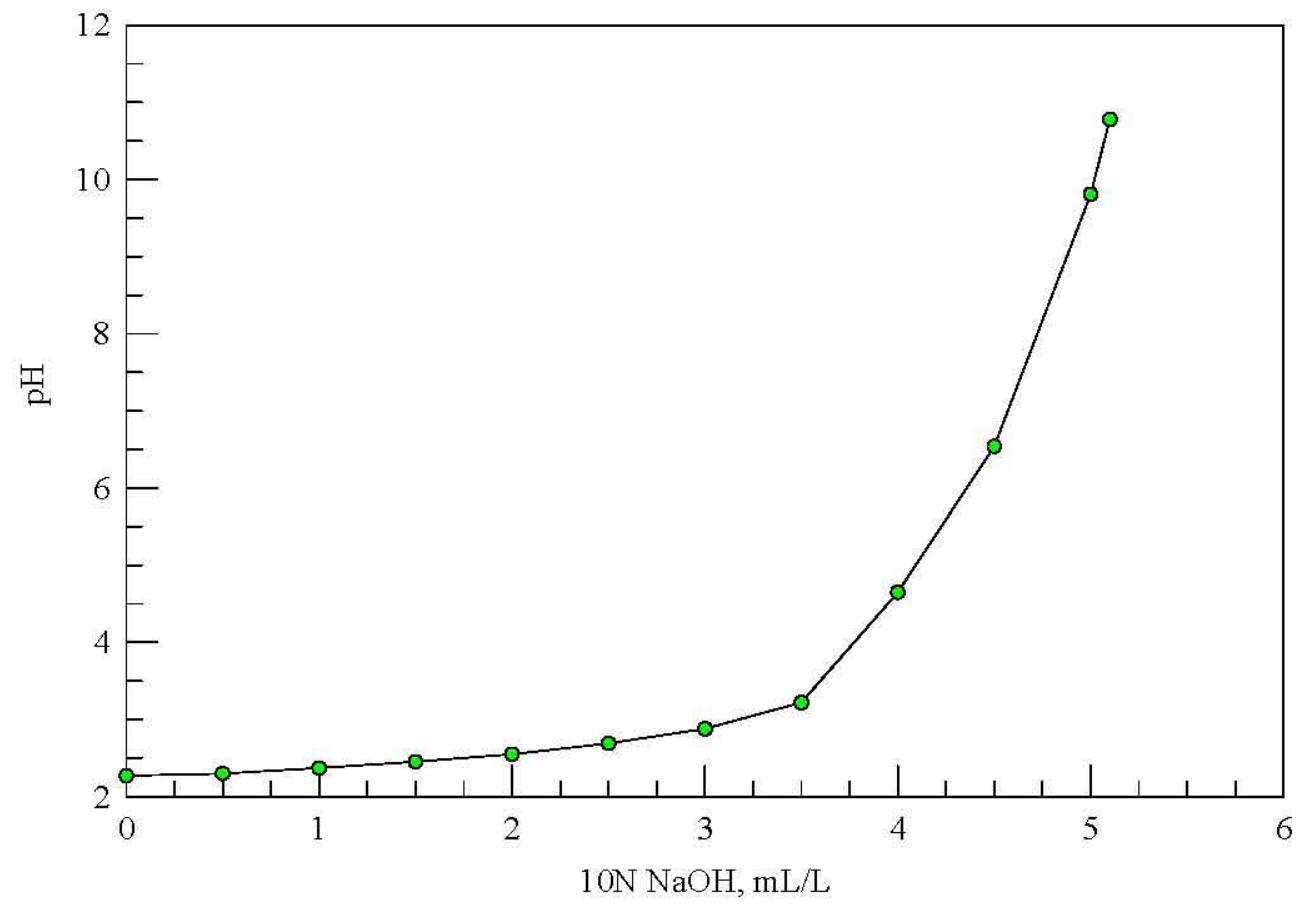




\subsection{SIMULATED GROUNDWATER}

Once efficacy was established with a tap water matrix, simulated groundwater from Liquid Effluent Retention Facility Basin 43 was formulated. Table 1 shows the composition of the simulated groundwater (Table 11 in Appendix A).

Table 1. Liquid Effluent Retention Facility Basin 43 Groundwater Simulant.

\begin{tabular}{|l|l|r|}
\hline \multicolumn{1}{|c|}{ Component } & \multicolumn{1}{c|}{ Formula } & g/L \\
\hline Deionized water & $\mathrm{H}_{2} \mathrm{O}$ & 740.4 \\
\hline Sodium sulfate & $\mathrm{Na}_{2} \mathrm{SO}_{4}$ & 38.7 \\
\hline Calcium sulfate & $\mathrm{CaSO}_{4} * 2 \mathrm{H}_{2} \mathrm{O}$ & 126.1 \\
\hline Calcium nitrate & $\mathrm{Ca}\left(\mathrm{NO}_{3}\right)_{2} * 4 \mathrm{H}_{2} \mathrm{O}$ & 85.7 \\
\hline Magnesium nitrate & $\mathrm{Mg}\left(\mathrm{NO}_{3}\right)_{2} * 6 \mathrm{H}_{2} \mathrm{O}$ & 127.4 \\
\hline Magnesium chloride & $\mathrm{MgCl}_{2} * 6 \mathrm{H}_{2} \mathrm{O}$ & 15.9 \\
\hline Potassium chloride & $\mathrm{KCl}$ & 5.9 \\
\hline
\end{tabular}

The simulant (referred to hereafter as Basin 43) was titrated with $0.5 \mathrm{M}$ sodium metabisulfite. During the first titration, the $\mathrm{pH}$ was not controlled and drifted to a final $\mathrm{pH}$ of 3.25 , requiring $41 \mathrm{~mL}$ of sodium metabisulfite to reach an ORP end point of $270 \mathrm{mV}$ (Table 12 in Appendix A).

The experiment was re-run maintaining tight control of the $\mathrm{pH}$ level, which required $30 \mathrm{~mL}$ of sodium metabisulfite to reach an end point of $280 \mathrm{mV}$ (Table 14 in Appendix A).

Figure 4 shows the titration curve obtained from the data presented in Table 14 of Appendix A. The concentration of $\mathrm{Cr}(\mathrm{VI})$ is not plotted on this figure, as the initial value was $110 \mathrm{mg} / \mathrm{L}$; at an ORP of $550 \mathrm{mV}$, Cr(VI) was $10 \mathrm{mg} / \mathrm{L}$; and at an ORP of $307 \mathrm{mV}, \mathrm{Cr}(\mathrm{VI})$ is less than $0.01 \mathrm{mg} / \mathrm{L}$.

Figure 5 shows the titration curve to obtain a $\mathrm{pH}$ greater than 10.5 for Basin 43 (Table 15 in Appendix A). 
RPP-RPT-34083, Rev. 0

Figure 4. Cumulative Volume of 0.5 M Sodium Metabisulfite to Achieve an ORP of 280 at pH 2 in Basin 43 Simulant at $110 \mathrm{mg} / \mathrm{L}$ Cr(VI).

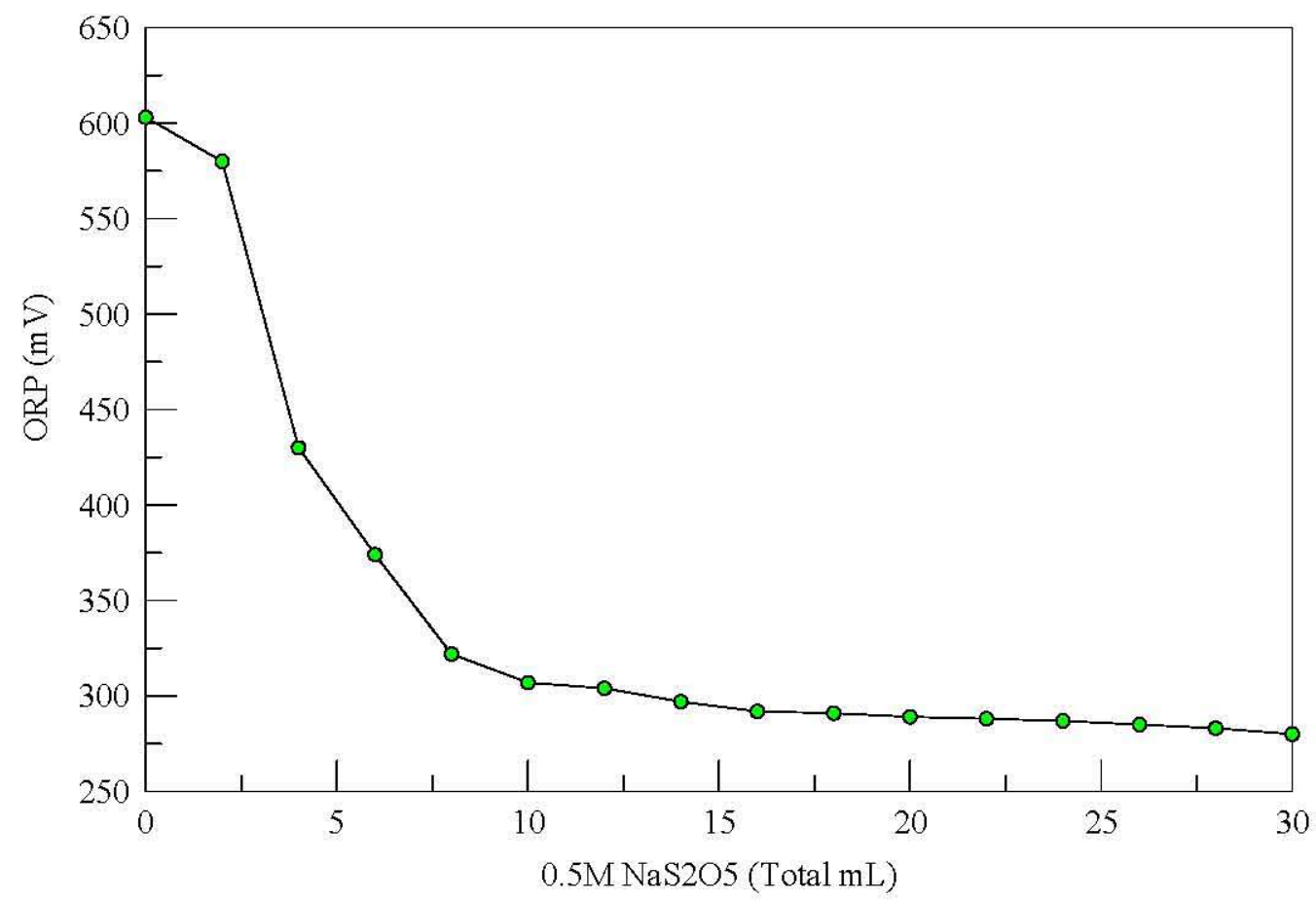

Figure 5. Cumulative Volume of 10N Sodium Hydroxide to Achieve a pH Greater than 10.5 .

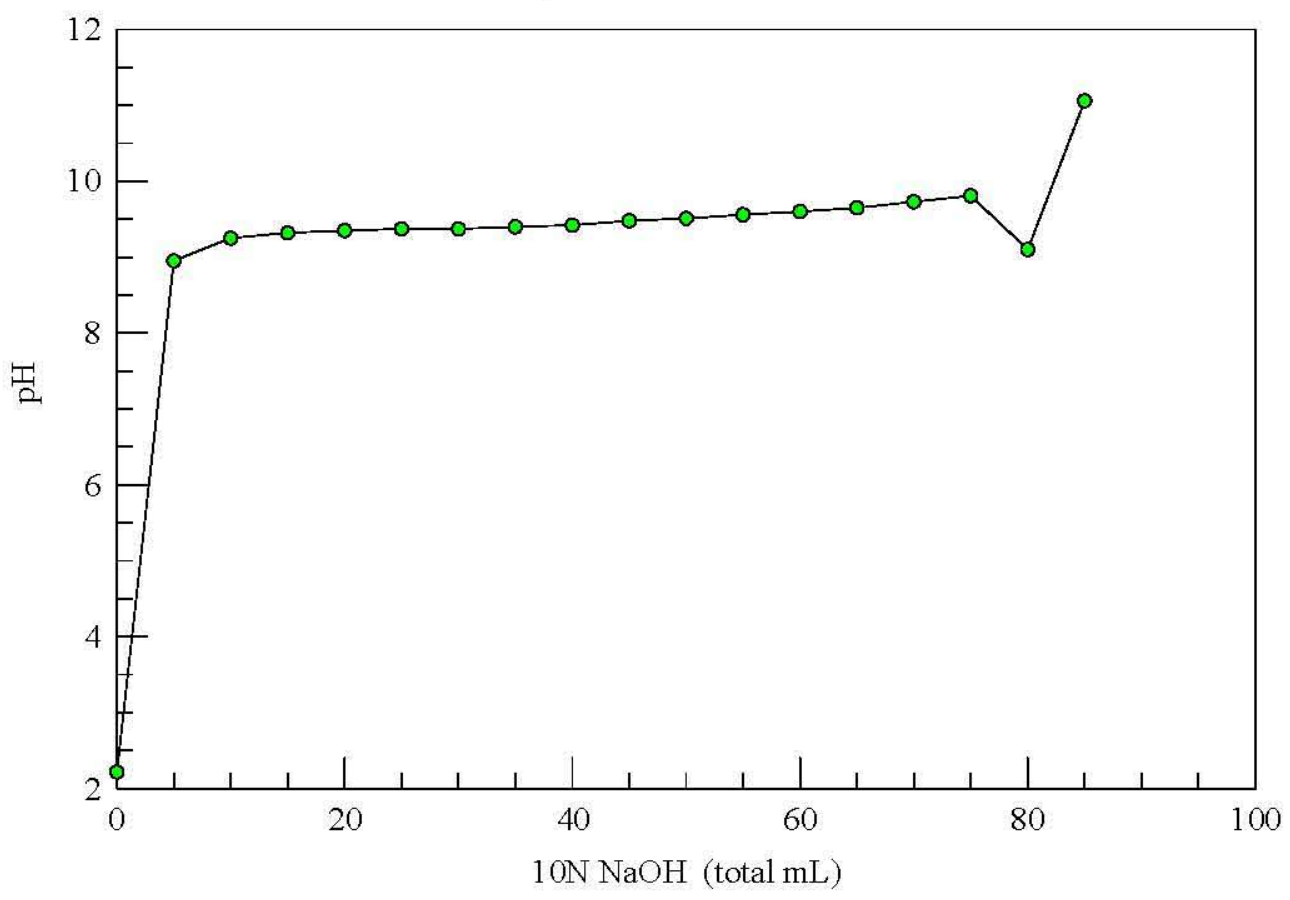


RPP-RPT-34083, Rev. 0

\subsection{TOXICITY CHARACTERISTIC LEACHING PROCEDURE RESULTS}

The results from the TCLP are presented in Table 2 (Table 18 of Appendix A).

Table 2. Toxicity Characteristic Leaching Procedure Results.

\begin{tabular}{|c|c|c|}
\hline $\begin{array}{c}\text { Reference Table } \\
\text { in Appendix A }\end{array}$ & $\mathbf{p H}$ & $\begin{array}{c}\text { Total Cr } \\
\text { (ppm) }\end{array}$ \\
\hline Table 15 & 9.10 & 17.65 \\
\hline Table 15 & 11.06 & 0.085 \\
\hline Table 17 & 10.6 & 2.79 \\
\hline Table 17 & 11.5 & 3.4 \\
\hline
\end{tabular}

As shown in Table 2, the higher $\mathrm{pH}$ samples were successful in yielding a successful TCLP. The sample at the $\mathrm{pH}$ level of 11.5 yielded a higher total $\mathrm{ppm} \mathrm{Cr}$ than the $11.06 \mathrm{pH}$. This may be because the laboratory ran the $11.06 \mathrm{pH}$ sample in a shorter time frame, and the $11.5 \mathrm{pH}$ sample was allowed to sit stagnant for several weeks. During this time enough carbon dioxide may have been taken up to lower the $\mathrm{pH}$ from the initially measured $\mathrm{pH}$ of 11.5 .

\section{CONCLUSIONS}

The use of sodium metabisulfite to reduce $\mathrm{Cr}$ (VI) to Cr(III) is an efficacious method if the solution is maintained at close to $\mathrm{pH}$ 2. When precipitating $\mathrm{Cr}(\mathrm{OH})_{3}$ by the addition of $\mathrm{NaOH}$, it is best to attain a $\mathrm{pH}$ of 11 to 11.5 to ensure a TCLP of less than $5 \mathrm{ppm}$.

\section{REFERENCES}

Application Data Sheet, ADS 3300-02/rev.A, August 2004, pH and ORP Control for Removing Chrome from Plant Effluent, in Metals and Mineral Industry, Emerson Process Management, http://www.emersonprocess.com/raihome/documents/Liq_AppData 330002.pdf.

Cushnie, G. C., 1994, Pollution Prevention and Control Technology for Plating Operations, National Center for Manufacturing Sciences, Ann Arbor, Michigan.

Method 1311, "Toxicity Characteristic Leaching Procedure," SW-846, Test Methods for Evaluating Solid Waste, Physical/Chemical Methods, Third Edition, as amended, U.S. Environmental Protection Agency, Washington, D.C., September 1986.

RPP-PLAN-32738, 2007, Test Plan for the Effluent Treatment Facility to Reduce Chrome(VI) to Chrome(III) in the Secondary Waste Stream, Rev. 1, CH2M HILL Hanford Group, Inc., Richland, Washington. 
RPP-RPT-34083, Rev. 0

Appendix A

Center for Laboratory Sciences Report 


\section{Effluent Treatment Facility Secondary Waste Stream Chrome Reduction Study}

Prepared by:

RJ LeeGroup, Inc.

Center for Laboratory Sciences 2710 North $20^{\text {th }}$ Avenue

Pasco, WA 99301

www.rilg.com

\author{
Laboratory Report \\ Report Date: June 28, 2007 \\ Technical Manager, Dr. Joe Sears \\ Author, Marisol Avila
}

Document No: CLSR2007-1

CMR0760

Document No: CLSR2007-1 


\section{Table of Contents}

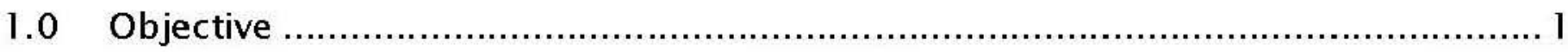

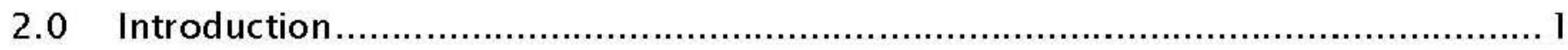

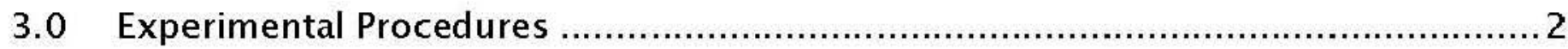

3.1 Phase I, Sodium Sulfate Solution, Hexavalent Chrome, Sodium Metabisulfite Addition .......................................................................................... 2

3.1.1 Phase I, Case la- pH 2 Sodium sulfate/Sodium chromate Solution Titration with Sodium Metabisulfite............................................. 3

3.1.2 Phase I, Case Ib- pH 4 Sodium sulfate/Sodium chromate Solution Titration with Sodium Metabisulfite............................................. 6

3.2 Phase I, Case I Experimental Results...................................................... 7

3.3 Phase I, Case 2 - Trisodium Phosphate to bind Chromium (III) ................... 8

3.4 Phase I, Case 2 Experimental Results ......................................................

3.5 Phase II, Case 1 - Basin 43 Groundwater Matrix ......................................

3.5.1 Phase II, Case 1- pH 2 Basin 43/Sodium Chromate Solution Titration with Sodium Metabisulfite............................................................. 10

3.6 Phase II, Case I Experimental Results .................................................. 15

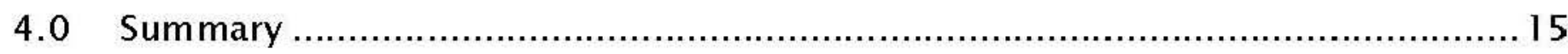




\section{List of Tables}

Table 1 - Calculation for 100 ppm of Hexavalent Chrome 3

Table 2 - $\mathrm{pH} 2$ sodium sulfate/sodium chromate solution titration to $300 \mathrm{mV}$-Trial \#1 ............... 3

Table 3- pH 2 reduced chrome solution titrated to $\mathrm{pH} 10-$ Trial $\# 1$...........................................4

Table 4- $\mathrm{pH} 2$ sodium sulfate/sodium chromate solution titrated to $280 \mathrm{mV}$-Trial \#2 ............... 5

Table 5- $\mathrm{pH} 2$ reduced chrome solution titrated to $\mathrm{pH} 10.5$-Trial \#2 .......................................... 6

Table 6 - pH 4 sodium sulfate/sodium chromate solution titrated to $258 \mathrm{mV}$............................. 7

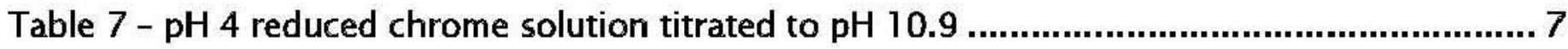

Table 8 - TCLP results for $\mathrm{pH} 2$ and $\mathrm{pH} 4$ reduced chrome experiments ................................... 7

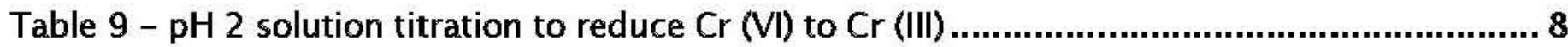

Table 10 - Titration with $0.5 \mathrm{M}$ Trisodium phosphate to bind $\mathrm{Cr}$ (III) ........................................9

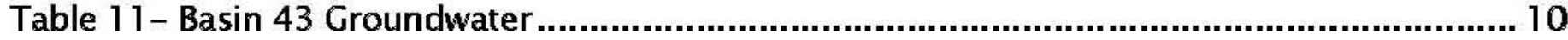

Table 12 - pH 2 Basin 43 Groundwater/sodium chromate solutions titrated to $270 \mathrm{mV}$ - Trial \#110

Table 13- $\mathrm{pH} 2$ reduced Basin 43 chrome solution titrated to $\mathrm{pH} 10.9$ Trial \#1

Table 14- $\mathrm{pH} 2$ Basin 43 Groundwater/sodium chromate solutions titrated to $270 \mathrm{mV}$ - Trial \#212 Table 15- pH 2 reduced Basin 43 chrome solution titrated to $\mathrm{pH} 11.06$ Trial \#2 ........................ 13

Table 16- $\mathrm{pH} 2$ Basin 43 Groundwater/sodium chromate solutions titrated to $270 \mathrm{mV}$ - Trial \#313 Table 17- $\mathrm{pH} 2$ reduced Basin 43 chrome solution titrated to $\mathrm{pH} 11.5$-Trial \#3 .......................... 14

Table 18- TCLP and $\mathrm{Cr}^{6}+$ results for $\mathrm{pH} 2$ Basin 43 reduced chrome experiments...................... 15

\section{List of Figures}

Figure 1 - ORP (mv) versus Reagent Addition 


\subsection{Objective}

The Center for Laboratory Sciences (CLS) was sought out to perform a series of laboratory experimental activities in support of Fluor Hanford's demonstration of the use of sodium metabisulfite to reduce hexavalent chromium to its more stable trivalent form. Under the direction of Fluor Hanford and CH2M Hill's technical personnel, the laboratory tasks in Phase 1 and Phase 2 of this demonstration were performed as follows: sodium metabisulfite titrations using tap water and Basin 43 groundwater as matrices, Toxicity Characteristic Leaching Procedure (TCLP) method of the final titrated solutions at various $\mathrm{pH}$ targets, and analytical testing using inductively coupled plasma-mass spectrometry and ion chromatography for chromium concentrations. The experimental procedures and results are presented in this report.

\subsection{Introduction}

At present time the Effluent Treatment Facility (ETF) has several waste streams which are processed through their Thin Film Dryer. As part of this process, the waste has to pass final disposal restrictions in order to be disposed of in the Environmental Restoration Disposal Facility (ERDF) landfill. One of the major setbacks for disposal has been the inability to decrease the mobility of chrome in the environment. Therefore, it has been proposed to test the efficiency of using sodium metabisulfite to reduce hexavalent chromium (Cr (VI) to the more stable trivalent form of chromium (Cr (III). The reduction of $\mathrm{Cr}$ (VI) to $\mathrm{Cr}$ (III) will decrease the mobility of chromium in the environment, allowing the waste streams from the ETF Thin Film Dryer to pass the Method 1311, "Toxicity Characteristic Leaching Procedure" (TCLP).

It has been determined elsewhere, that sodium metabisulfite, when added to water, forms sodium bisulfite. In the presence of acid, the sodium bisulfite has the following reaction (Pollution Prevention and Control Technology for Plating Operations, Cushnie, 1994):

$\mathrm{Na}_{2} \mathrm{~S}_{2} \mathrm{O}_{5}+\mathrm{H}_{2} \mathrm{O} \rightarrow 2 \mathrm{NaHSO}_{3}$

(1)

Then

$3 \mathrm{NaHSO}_{3}+2 \mathrm{H}_{2} \mathrm{CrO}_{4}+3 \mathrm{H}_{2} \mathrm{SO}_{4} \rightarrow \mathrm{Cr}_{2}\left(\mathrm{SO}_{4}\right)_{3}+5 \mathrm{H}_{2} \mathrm{O}+3 \mathrm{NaHSO}_{4}$

(2)

After the hexavalent chromium is reduced to the trivalent state, it is then reacted with caustic to precipitate chromium hydroxide $\left[\mathrm{Cr}(\mathrm{OH})_{3}\right]$.

$$
\mathrm{Cr}_{2}\left(\mathrm{SO}_{4}\right)_{3}+3 \mathrm{NaOH} \rightarrow 2 \mathrm{Cr}(\mathrm{OH})_{3}+3 \mathrm{Na}_{2} \mathrm{SO}_{4}
$$

During the course of the experiments, $\mathrm{Cr}$ (VI) and total $\mathrm{Cr}$ will be determined using ion chromatography and inductively coupled plasma-mass spectroscopy, respectively. 
Since there is no laboratory method for Cr (III), the difference between Cr (VI) and total $\mathrm{Cr}$ is assumed to be $\mathrm{Cr}$ (III) due to the above reduction reaction (Equation 2).

It is expected that sodium metabisulfite will be successful at the lower $\mathrm{pH}$ ranges and at an oxidation reduction potential (ORP) of approximately $+280 \mathrm{mV}$, Figure 1 (ADS $3300-02 /$ rev. A).

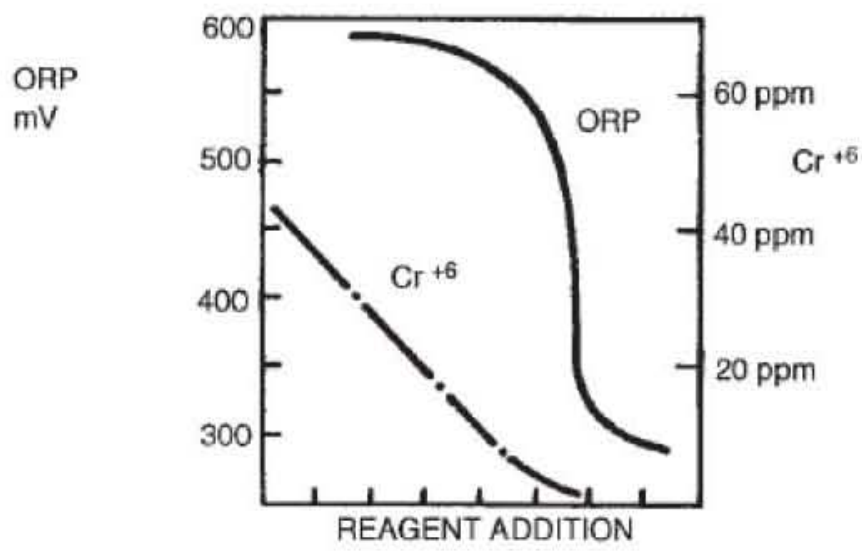

Figure 1-IORP (mV) versus Reagent Addition

\subsection{Experimental Procedures}

The testing for this effort was divided into two phases. Phase one consisted of case experiments in which the matrix was tap water. Case 1 was used to determine the baseline with $20 \mathrm{wt} \%$ sodium sulfate $\left(\mathrm{Na}_{2} \mathrm{SO}_{4}\right)$ and hexavalent chrome. Sodium metabisulfite $\left(\mathrm{Na}_{2} \mathrm{~S}_{2} \mathrm{O}_{5}\right)$ was incorporated to establish its effectiveness at reducing the oxidation-reduction potential (ORP) as a function of $\mathrm{pH}$. Case 2 used trisodium phosphate as a method to bind the trivalent chromium from the most promising experiment from Case 1 . Those experiments which provided promising results based on initial analysis were prepared for TCLP testing.

Phase two of the procedures utilized Basin 43 Groundwater as the matrix, which is an ETF waste stream at this time. The most successful parameters in Phase one, which yielded the most reduction of chrome (VI) from the TLCP, was used to prepare the mixture for this particular phase. Those experiments which provided promising results based on initial analysis were prepared for TCLP testing.

\subsection{Phase I, Sodium Sulfate Solution, Hexavalent Chrome, Sodium Metabisulfite Addition}

For all the Phase 1 experiments, a 1 -Liter $20 \mathrm{wt} \%$ sodium sulfate $\left(\mathrm{Na}_{2} \mathrm{SO}_{4}\right)$ solution was prepared in a volumetric flask. Approximately $100 \mathrm{ppm}$ of chrome in the form of sodium chromate $\left(\mathrm{Na}_{2} \mathrm{CrO}_{4}{ }^{*} 4 \mathrm{H}_{2} \mathrm{O}\right)$ was added to the solution. The calculation for 100 ppm is provided in Table 1 . The solution was then adjusted to a designated $\mathrm{pH}$ of 
either 2 or 4 . This solution was then titrated with $0.5 \underline{\mathrm{M}}$ sodium metabisulfite $\left(\mathrm{Na}_{2} \mathrm{~S}_{2} \mathrm{O}_{5}\right)$ to achieve an ORP reading close to $280 \mathrm{mV}$. Aliquots during the titration were removed at different intervals and tested with a $\mathrm{HACH}$ test meter for Chrome (VI). After the completion of the titration to a reduced $\mathrm{pH}$, a titration was performed to increase the $\mathrm{pH}$ to $>10$. Samples were retrieved and dried at $180^{\circ} \mathrm{C}$ for TLCP analysis for total Cr.

\section{Table 1 - Calculation for 100 ppm of Hexavalent Chrome}

\begin{tabular}{|c|c|c|}
\hline Component & $\begin{array}{c}\mathrm{FW} \\
(\mathrm{gram} / \text { mole })\end{array}$ & $\begin{array}{c}\mathrm{Cr}^{6+} \\
(100 \mathrm{ppm})\end{array}$ \\
\hline $\mathrm{Na} 2 \mathrm{CrO}^{+} 4 \mathrm{H} 2 \mathrm{O}$ & 234.04 & 0.4501 grams \\
\hline $\mathrm{Cr}$ (metal) & 52.00 & $\mathrm{~N} / \mathrm{A}$ \\
\hline
\end{tabular}

\subsubsection{Phase I, Case la- $\mathrm{pH} 2$ Sodium sulfate/Sodium chromate Solution Titration with}

\section{Sodium Metabisulfite}

A 1-Liter batch of the sodium sulfate and sodium chromate mixture was prepared. The mixture appeared dark yellow in color, with a milky consistency. The solution was adjusted to $\mathrm{pH} 2$ with an initial addition of $1 \mathrm{~mL}$ of $0.1 \mathrm{~N}$ sulfuric acid, and then $0.8 \mathrm{~mL}$ of $2 \mathrm{~N}$ sulfuric acid and a final addition of $2 \mathrm{~mL}$ of concentrated $92 \%$ sulfuric acid to achieve a $\mathrm{pH}$ of 2.05. The corresponding ORP was $658 \mathrm{mV}$. The mixture was then titrated with sodium metabisulfite to attain an ORP of at least $300 \mathrm{mV}$ to provide the most reduction of chrome. The actual amounts used for this experiment are provided in Table 2.

Table 2 - $\mathrm{pH} 2$ sodium sulfate/sodium chromate solution titration to $300 \mathrm{mV}$-Trial \#1

\begin{tabular}{|c|c|c|c|c|c|}
\hline Color of solution & $\begin{array}{c}0.5 \mathrm{M} \mathrm{NaS}_{2} \mathrm{O}_{5} \\
(\text { Total } \mathrm{mL})\end{array}$ & $\begin{array}{c}\mathrm{ORP} \\
(\mathrm{mV})\end{array}$ & $\mathrm{pH}$ & $\begin{array}{c}\text { aliquots } \\
\text { taken }\end{array}$ & $\begin{array}{c}\mathrm{HACH} \\
\mathrm{Cr}(\mathrm{VI}) \\
\text { reading }\end{array}$ \\
\hline yellow & 0.0 & 669 & 2.05 & $\mathrm{~N} / \mathrm{A}$ & $\mathrm{N} / \mathrm{A}$ \\
\hline yellow & 0.5 & 671 & 2.05 & $\mathrm{~N} / \mathrm{A}$ & $\mathrm{N} / \mathrm{A}$ \\
\hline yellow & 1.0 & 657 & 2.05 & $\mathrm{~N} / \mathrm{A}$ & $\mathrm{N} / \mathrm{A}$ \\
\hline yellow & 1.5 & 651 & 2.05 & $\mathrm{~N} / \mathrm{A}$ & $\mathrm{N} / \mathrm{A}$ \\
\hline yellow & 2.0 & 650 & 2.05 & $\mathrm{~N} / \mathrm{A}$ & $\mathrm{N} / \mathrm{A}$ \\
\hline yellow to light green & 2.5 & 634 & 2.05 & $\mathrm{~N} / \mathrm{A}$ & $\mathrm{N} / \mathrm{A}$ \\
\hline light green & 3.0 & 615 & 2.05 & $\mathrm{~N} / \mathrm{A}$ & $\mathrm{N} / \mathrm{A}$ \\
\hline medium green & 3.5 & 603 & 2.05 & $1 \mathrm{st}$ & $18 \mathrm{ppm}$ \\
\hline medium to blue green & 4.0 & 448 & 2.05 & $2 \mathrm{nd}$ & $\mathrm{N} / \mathrm{A}$ \\
\hline light blue/pale green & 4.5 & 355 & 2.05 & $3 \mathrm{rd}$ & $\mathrm{N} / \mathrm{A}$ \\
\hline light blue & 5.0 & 327 & 2.05 & 4 th & N/A \\
\hline light blue & 5.5 & 319 & 2.05 & 5 th & N/A \\
\hline light blue & 6.0 & 315 & 2.05 & 6 th & N/A \\
\hline light blue & 6.5 & 313 & 2.05 & 7 th & $0.11 \mathrm{ppm}$ \\
\hline
\end{tabular}


As shown in Table 1, the chrome (VI) reduction is evident due to the color change from yellow to green to blue. A Hach test meter was used to do intermediate readings from aliquots pulled throughout the titration. The chrome (VI) initially should be close to $100 \mathrm{ppm}$ and based on the readings dropped to $0.11 \mathrm{ppm}$ after titration. This solution was then titrated to a $\mathrm{pH}$ greater than 10 with $10 \underline{\mathrm{N}}$ sodium hydroxide. The results from that experiment are provided in Table 3.

\section{Table 3- $\mathrm{pH} 2$ reduced chrome solution titrated to $\mathrm{pH}$ 10-Trial \#1}

\begin{tabular}{|c|c|c|}
\hline $\begin{array}{c}10 \mathrm{~N} \\
\text { (total } \mathrm{NL} \text { ) }\end{array}$ & $\mathrm{pH}$ & Color change \\
\hline 0.0 & 2.05 & Light blue \\
\hline 0.5 & 2.15 & Light blue \\
\hline 1.0 & 2.22 & Light blue \\
\hline 1.5 & 2.3 & Light blue \\
\hline 2.0 & 2.4 & Light blue \\
\hline 2.5 & 2.53 & Light blue \\
\hline 3.0 & 2.71 & Light blue \\
\hline 3.5 & 3.02 & Light blue \\
\hline 4.0 & 4.35 & Light blue \\
\hline 4.5 & 9.46 & Cloudy blue color \\
\hline 4.6 & 10.81 & Cloudy blue color \\
\hline
\end{tabular}

An observation from this titration was an increase in the amount of solids precipitated from the solution as the $\mathrm{pH}$ increased to 10 . These solids are thought to be mainly $\mathrm{Cr}$ (III).

This experiment was repeated to validate the results. The working solution of sodium sulfate and sodium chromate had an initial $\mathrm{pH}$ of 7.73 with an ORP of $260 \mathrm{mV} .1 .78 \mathrm{~mL}$ of concentrated sulfuric acid was used to reduce the $\mathrm{pH}$ to 2.01 . The results of the titration with $0.5 \mathrm{M}$ sodium metabisulfite are provided in Table 4. 
Table 4- $\mathrm{pH} 2$ sodium sulfate/sodium chromate solution titrated to $280 \mathrm{mV}$ - Trial \#2

\begin{tabular}{|c|c|c|c|c|c|}
\hline Color of solution & $\begin{array}{c}0.5 \mathrm{M} \mathrm{NaS} \mathrm{O}_{5} \\
\text { (Total } \mathrm{mL} \text { ) }\end{array}$ & $\begin{array}{l}\text { ORP } \\
(\mathrm{mV})\end{array}$ & $\mathrm{pH}$ & $\begin{array}{c}\text { aliquots } \\
\text { taken }\end{array}$ & $\begin{array}{l}\mathrm{HACH} \mathrm{Cr}(\mathrm{VI}) \\
\text { reading }(\mathrm{ppm})\end{array}$ \\
\hline bright yellow & 0.0 & 684 & 2.04 & 1st & 80 \\
\hline slight color change & 0.5 & 659 & 2.05 & $\mathrm{~N} / \mathrm{A}$ & N/A \\
\hline hint of green & 1.0 & 637 & 2.05 & N/A & N/A \\
\hline slightly more green & 1.5 & 615 & 2.06 & $\mathrm{~N} / \mathrm{A}$ & N/A \\
\hline lime green & 2.0 & 600 & 2.07 & 2nd & 40 \\
\hline green & 2.5 & 583 & 2.07 & N/A & N/A \\
\hline touch of blue & 3.0 & 470 & 2.08 & N/A & 10 \\
\hline light blue & 3.5 & 359 & 2.08 & $N / A$ & N/A \\
\hline light blue & 4.0 & 338 & 2.07 & $3 r d$ & 0.02 \\
\hline light blue & 4.5 & 322 & 2.08 & $\mathrm{~N} / \mathrm{A}$ & N/A \\
\hline light blue & 5.0 & 316 & 2.08 & N/A & $\mathrm{N} / \mathrm{A}$ \\
\hline light blue & 5.5 & 310 & 20.6 & N/A & N/A \\
\hline light blue & 6.0 & 304 & 2.06 & N/A & $N / A$ \\
\hline light blue & 6.5 & 300 & 2.08 & 4th & No reading \\
\hline light blue & 7.0 & 296 & 2.09 & N/A & $\mathrm{N} / \mathrm{A}$ \\
\hline light blue & 7.5 & 294 & 2.09 & N/A & N/A \\
\hline light blue & 8.0 & 292 & 2.09 & N/A & N/A \\
\hline light blue & 8.5 & 290 & 2.10 & N/A & N/A \\
\hline light blue & 9.0 & 289 & 2.10 & N/A & N/A \\
\hline light blue & 9.5 & 287 & 2.10 & N/A & N/A \\
\hline light blue & 10.0 & 286 & 2.10 & N/A & N/A \\
\hline light blue & 10.5 & 285 & 2.10 & N/A & $\mathrm{N} / \mathrm{A}$ \\
\hline light blue & 11.0 & 284 & 2.10 & $\mathrm{~N} / \mathrm{A}$ & N/A \\
\hline light blue & 11.5 & 283 & 2.11 & N/A & $N / A$ \\
\hline light blue & 12.0 & 282 & 2.11 & N/A & N/A \\
\hline light blue & 12.5 & 281 & 2.11 & N/A & $N / A$ \\
\hline light blue & 13.0 & 279 & 2.11 & 5th & No reading \\
\hline
\end{tabular}

The solution was then titrated to a $\mathrm{pH}$ of 10.5 or greater with $10 \underline{\mathrm{N}} \mathrm{NaOH}$. The results are provided in Table 5. 
RPP-RPT-34083, Rev. 0

Reduction from Chrome (VI) to Chrome (III)

Laboratory Report

Table 5- $\mathrm{pH} 2$ reduced chrome solution titrated to $\mathrm{pH} 10.5-$ Trial \#2

\begin{tabular}{|c|c|c|}
\hline $\begin{array}{c}10 \mathrm{~N} \mathrm{NaOH} \\
\text { total } \mathrm{mL})\end{array}$ & $\mathrm{pH}$ & Color change \\
\hline 0.0 & 2.27 & Light blue \\
\hline 0.5 & 2.3 & Light blue \\
\hline 1.0 & 2.37 & Light blue \\
\hline 1.5 & 2.45 & Light blue \\
\hline 2.0 & 2.55 & Light blue \\
\hline 2.5 & 2.69 & Light blue \\
\hline 3.0 & 2.88 & Light blue \\
\hline 3.5 & 3.22 & Light blue \\
\hline 4.0 & 4.65 & Light blue \\
\hline 4.5 & 6.54 & Light blue \\
\hline 5.0 & 9.81 & Cloudy blue color \\
\hline 5.1 & 10.78 & Cloudy blue color ${ }^{*}$ \\
\hline
\end{tabular}

${ }^{* *}$ A sample of this final batch was put aside and dried for total $\mathrm{Cr}$ and $\mathrm{Cr}^{6+}$ analysis.

As seen previously in Case 1a Trial \#1, the titration with caustic caused solids to precipitate from the solution as the $\mathrm{pH}$ increased to 10 . These solids are thought to be mainly $\mathrm{Cr}$ (III). A sample was retrieved for TCLP analysis of total $\mathrm{Cr}$ and hexavalent Cr. These results will be discussed later in this report in Section 3.1.2.1. .

\subsubsection{Phase I, Case 1b- pH 4 Sodium sulfate/Sodium chromate Solution Titration with Sodium Metabisulfite}

A 1-Liter batch of the sodium sulfate and sodium chromate mixture was prepared. The mixture appeared dark yellow in color, with a milky consistency. The solution had an initial $\mathrm{pH}$ of 7.71 and was adjusted to $\mathrm{pH} 4.00$ with an initial addition of $0.1 \mathrm{~mL}$ of concentrated $92 \%$ sulfuric acid followed by an addition of $1.25 \mathrm{~mL}$ of $0.1 \underline{\mathrm{N}}$ sulfuric acid. The corresponding ORP was $457 \mathrm{mV}$. The mixture was then titrated with sodium metabisulfite to attain an ORP of at least $300 \mathrm{mV}$ to provide the most reduction of chrome. The actual amounts used for this experiment are provided in Table 6. 
Table 6 - $\mathrm{pH} 4$ sodium sulfate/sodium chromate solution titrated to $258 \mathrm{mV}$

\begin{tabular}{|c|c|c|c|c|c|}
\hline Color of solution & $\begin{array}{c}0.5 \mathrm{M} \mathrm{NaS} \mathrm{O}_{5} \\
(\mathrm{~mL})\end{array}$ & $\begin{array}{c}\mathrm{ORP} \\
(\mathrm{mV})\end{array}$ & $\mathrm{pH}$ & $\begin{array}{c}\text { aliquots } \\
\text { taken }\end{array}$ & $\begin{array}{c}\mathrm{HACH} \mathrm{Cr}(\mathrm{VI}) \\
\text { reading }(\mathrm{ppm})\end{array}$ \\
\hline bright yellow & 0.0 & 457 & 4.01 & 1 st & 110 \\
\hline darker yellow & 0.5 & 377 & 4.13 & $\mathrm{~N} / \mathrm{A}$ & $\mathrm{N} / \mathrm{A}$ \\
\hline very slight hint of green/yellow & 1.0 & 339 & 4.45 & $\mathrm{~N} / \mathrm{A}$ & $\mathrm{N} / \mathrm{A}$ \\
\hline very slight hint of green/yellow & 1.5 & 313 & 4.75 & $2 \mathrm{nd}$ & 70 \\
\hline slight green & 2.0 & 296 & 4.88 & $\mathrm{~N} / \mathrm{A}$ & 40 \\
\hline light green & 2.5 & 280 & 5.03 & $\mathrm{~N} / \mathrm{A}$ & 45 \\
\hline green & 3.0 & 267 & 5.16 & $\mathrm{~N} / \mathrm{A}$ & 27 \\
\hline green & 3.5 & 258 & 5.2 & N/A & 28 \\
\hline
\end{tabular}

The solution was then titrated to a $\mathrm{pH}$ of 10.5 or greater with $10 \mathrm{~N} \mathrm{NaOH}$. The results are provided in Table 7 .

Table $7-\mathrm{pH} 4$ reduced chrome solution titrated to $\mathrm{pH} 10.9$

\begin{tabular}{|c|c|c|}
\hline $\begin{array}{c}10 \mathrm{~N} \mathrm{NaOH} \\
\text { (total } \mathrm{mL} \text { ) }\end{array}$ & $\mathrm{pH}$ & Color Change \\
\hline 0.0 & 4.75 & N/A \\
\hline 0.5 & 10.94 & no visible color change ${ }^{\star \star}$ \\
\hline
\end{tabular}

${ }^{* *}$ A sample of this final batch was put aside and dried for total $\mathrm{Cr}$ and $\mathrm{Cr}^{6+}$ analysis.

As seen previously in Case $1 \mathrm{a}$, the titration with caustic caused solids to precipitate from the solution as the $\mathrm{pH}$ increased to 10 . However, the amount of solids appeared to be less than the experiments at $\mathrm{pH}$ 2. These solids are thought to be mainly $\mathrm{Cr}$ (III). A sample was retrieved for TCLP analysis of total $\mathrm{Cr}$ and hexavalent $\mathrm{Cr}$. These results will be discussed in Section 3.1.2.1.

\subsection{Phase I, Case I Experimental Results}

After completion of Case 1, all of the data regarding TCLP analysis for total $\mathrm{Cr}$ and $\mathrm{Cr}^{6+}$ were compiled and reviewed to determine the most promising mixture of the two $\mathrm{pH}$ endpoints to proceed further testing. Total chrome analysis was performed using a Perkin-Elmer ICP/MS. The hexavalent chrome was quantified using ion chromatography. The TCLP results for the $\mathrm{pH} 2$ and $\mathrm{pH} 4$ mixtures denoted by an asterisk $\left(^{*}\right)$ in Tables 4 and 6 are provided in Table 8.

Table 8 - TCLP results for $\mathrm{pH} 2$ and $\mathrm{pH} 4$ reduced chrome experiments

\begin{tabular}{|c|c|c|}
\hline $\mathrm{pH}$ & Total $\mathrm{Cr}(\mathrm{ppm})$ & $\begin{array}{c}\mathrm{Cr}^{6+} \\
(\mathrm{ppm})\end{array}$ \\
\hline $2 \rightarrow 10$ & 0.32575 & 0.00254 \\
\hline $4 \rightarrow 10$ & 0.32394 & 1.704 \\
\hline
\end{tabular}


As shown in Table 8 , the $\mathrm{pH} 2$ solution more effectively reduced the $\mathrm{Cr}^{6+}$ content although the total $\mathrm{Cr}$ quantity remained similar for both. Based on this observation, $\mathrm{pH} 2$ is the most promising $\mathrm{pH}$ to use for these experiments. An increase in $\mathrm{pH}$ would only decrease the effectiveness of the chrome reduction.

\subsection{Phase I, Case 2 - Trisodium Phosphate to bind Chromium (III)}

For Case 2, a working solution of the $\mathrm{pH} 2$ sodium sulfate/sodium chromate mixture was prepared, based on the results from the TCLP. The solution had an initial pH of 7.81 with an ORP of $230 \mathrm{mV}$. It was adjusted to $\mathrm{pH} 2.05$ with an addition of $2.2 \mathrm{~mL}$ of concentrated $92 \%$ sulfuric acid. The corresponding ORP was $658 \mathrm{mV}$. The mixture was then titrated with sodium metabisulfite to attain an ORP of at least $300 \mathrm{mV}$ to provide the most reduction of chrome. The actual amounts used for this experiment are provided in Table 9.

Table 9 - pH 2 solution titration to reduce $\mathrm{Cr}$ (VI) to $\mathrm{Cr}$ (III)

\begin{tabular}{|c|c|c|c|c|}
\hline Color of solution & $\begin{array}{c}0.5 \mathrm{M} \mathrm{NaS}_{2} \mathrm{O}_{5} \\
\text { (Total mL) }\end{array}$ & $\begin{array}{l}\text { ORP } \\
(\mathrm{mV})\end{array}$ & $\mathrm{pH}$ & $\begin{array}{l}\mathrm{HACH} \mathrm{Cr}(\mathrm{VI}) \\
\text { reading (ppm) }\end{array}$ \\
\hline dark yellow & 0.0 & 607 & 2.01 & 100 \\
\hline slightly cloudy & 0.5 & 599 & 2.02 & N/A \\
\hline very slight green & 1.0 & 588 & 2.02 & $\mathrm{~N} / \mathrm{A}$ \\
\hline light green & 1.5 & 578 & 2.02 & N/A \\
\hline green & 2.0 & 582 & 2.01 & $\mathrm{~N} / \mathrm{A}$ \\
\hline green & 2.5 & 579 & 1.97 & N/A \\
\hline blue green & 3.0 & 531 & 1.98 & N/A \\
\hline blue & 3.5 & 347 & 1.98 & N/A \\
\hline blue & 4.0 & 334 & 1.98 & N/A \\
\hline blue & 4.5 & 324 & 1.98 & N/A \\
\hline blue & 5.0 & 317 & 1.99 & $\mathrm{~N} / \mathrm{A}$ \\
\hline blue & 5.5 & 309 & 1.99 & $\mathrm{~N} / \mathrm{A}$ \\
\hline blue & 6.0 & 304 & 1.99 & N/A \\
\hline blue & 6.5 & 301 & 1.99 & N/A \\
\hline blue & 7.5 & 295 & 1.99 & N/A \\
\hline blue & 8.5 & 291 & 1.99 & $\mathrm{~N} / \mathrm{A}$ \\
\hline blue & 9.5 & 288 & 1.99 & N/A \\
\hline blue & 10.5 & 284 & 2.00 & N/A \\
\hline blue & 11.5 & 280 & 2.00 & 0.08 \\
\hline
\end{tabular}

This reduced chrome solution was then titrated with a $0.5 \underline{\mathrm{M}}$ trisodium phosphate solution in an effort to bind the remaining $\mathrm{Cr}$ (III), Table 10. 
Table 10 - Titration with $0.5 \mathrm{M}$ Trisodium phosphate to bind $\mathrm{Cr}$ (III)

\begin{tabular}{|c|c|c|c|}
\hline $\begin{array}{c}0.5 \mathrm{M} \mathrm{Na}_{3} \mathrm{PO}_{4} \\
(\text { Total } \mathrm{mL})\end{array}$ & $\begin{array}{c}\mathrm{ORP} \\
(\mathrm{mV})\end{array}$ & $\mathrm{pH}$ & $\begin{array}{c}\mathrm{HACH} \mathrm{Cr}(\mathrm{VI}) \\
\text { reading }(\mathrm{ppm})\end{array}$ \\
\hline 0.0 & 280 & 2.15 & 0.07 \\
\hline 0.5 & 310 & 2.15 & $\mathrm{~N} / \mathrm{A}$ \\
\hline 1.0 & 309 & 2.16 & $\mathrm{~N} / \mathrm{A}$ \\
\hline 1.5 & 308 & 2.16 & $\mathrm{~N} / \mathrm{A}$ \\
\hline 2.0 & 308 & 2.16 & $\mathrm{~N} / \mathrm{A}$ \\
\hline 2.5 & 308 & 2.17 & $\mathrm{~N} / \mathrm{A}$ \\
\hline 3.0 & 307 & 1.17 & $\mathrm{~N} / \mathrm{A}$ \\
\hline 3.5 & 307 & 2.18 & $\mathrm{~N} / \mathrm{A}$ \\
\hline 4.0 & 307 & 2.19 & $\mathrm{~N} / \mathrm{A}$ \\
\hline 5.0 & 306 & 2.2 & $\mathrm{~N} / \mathrm{A}$ \\
\hline 6.0 & 306 & 2.21 & $\mathrm{~N} / \mathrm{A}$ \\
\hline 7.0 & 305 & 2.24 & N/A \\
\hline 8.0 & 305 & 2.24 & N/A \\
\hline 9.0 & 305 & 2.24 & N/A \\
\hline 10.0 & 305 & 2.24 & No reading \\
\hline
\end{tabular}

During the titration with trisodium phosphate, there were no solids coming out of solution. A $15-\mathrm{mL}$ sample of $0.5 \mathrm{M}$ trisodium phosphate was added to $10-\mathrm{mL}$ of the ending solution in Table 10 above. The $\mathrm{pH}$ changed to 12.18 and no solids appeared. A titration with $10 \underline{N}$ sodium hydroxide was not necessary.

\subsection{Phase I, Case 2 Experimental Results}

Based on the observations from the experiment, it didn't appear that the trisodium phosphate was useful in binding the Cr (III) from the solution. This experiment was not continued any further.

\subsection{Phase II, Case I - Basin 43 Groundwater Matrix}

For all the Phase 2 experiments, there were at total of three trial mixtures. All of them were consisted of a 1-Liter solution of Basin 43 groundwater prepared according to the recipe in Table 11. Approximately $100 \mathrm{ppm}$ of chrome in the form of sodium chromate $\left(\mathrm{Na}_{2} \mathrm{CrO}_{4}{ }^{*} 4 \mathrm{H}_{2} \mathrm{O}\right)$ was added to the solution, as provided in Table 1 . The solution was then adjusted to a $\mathrm{pH}$ of 2 based on the success of this $\mathrm{pH}$ endpoint for the tap water matrix. This solution was then titrated with $0.5 \underline{\mathrm{M}}$ sodium metabisulfite $\left(\mathrm{Na}_{2} \mathrm{~S}_{2} \mathrm{O}_{5}\right)$ to achieve an ORP reading close to $280 \mathrm{mV}$. Aliquots during the titration were removed at different intervals and tested with a $\mathrm{HACH}$ test meter for Chrome (VI). After the completion of the titration to a reduced $\mathrm{pH}$, a titration with $10 \underline{\mathrm{N}} \mathrm{NaOH}$ was performed to increase the $\mathrm{pH}$ to $>10$. Samples were retrieved and dried at $180^{\circ} \mathrm{C}$ for TLCP analysis for total $\mathrm{Cr}$. 
RPP-RPT-34083, Rev. 0

Reduction from Chrome (VI) to Chrome (III)

Laboratory Report

Table 11- Basin 43 Groundwater

\begin{tabular}{|l|c|c|}
\hline \multicolumn{1}{|c|}{ Component } & Formula & gram/Liter \\
\hline Deionized Water & $\mathrm{H}_{2} \mathrm{O}$ & 740.4 \\
\hline Sodium Sulfate & $\mathrm{Na}_{2} \mathrm{SO}_{4}$ & 38.7 \\
\hline Calcium Sulfate & $\mathrm{CaSO}_{4}{ }^{*} 2 \mathrm{H}_{2} \mathrm{O}$ & 126.1 \\
\hline Calcium Nitrate & $\mathrm{Ca}\left(\mathrm{NO}_{3}\right)_{2}{ }^{*} 4 \mathrm{H}_{2} \mathrm{O}$ & 85.7 \\
\hline Magnesium Nitrate & $\mathrm{Mg}\left(\mathrm{NO}_{3}\right)_{2}{ }^{*} 6 \mathrm{H}_{2} \mathrm{O}$ & 127.4 \\
\hline Magnesium Chloride & $\mathrm{MgCl}_{2}{ }^{*} 6 \mathrm{H}_{2} \mathrm{O}$ & 15.9 \\
\hline Potassium Chloride & $\mathrm{KCl}$ & 5.9 \\
\hline
\end{tabular}

\subsection{Phase II, Case 1-pH 2 Basin 43/Sodium Chromate Solution Titration with Sodium Metabisulfite}

For Case 1, Trial \#1, a working solution of the $\mathrm{pH} 2$ Basin 43/sodium chromate mixture was prepared. The solution had an initial $\mathrm{pH}$ of 8.20 . It was adjusted to $\mathrm{pH} 2.06$ with an addition of $0.350 \mathrm{~mL}$ of concentrated $92 \%$ sulfuric acid. The corresponding ORP was $636 \mathrm{mV}$. The mixture was then titrated with sodium metabisulfite to attain an ORP of at least $300 \mathrm{mV}$ to provide the most reduction of chrome. The actual amounts used for this experiment are provided in Table 12. During the titration, the $\mathrm{pH}$ kept rising well beyond the 2.0 range. AT one point during the titration, concentrated sulfuric acid was added to adjust the $\mathrm{pH}$ back down to about 2.0. As a result, a large amount of sodium metabisulfite needed to be added to the solution in order to achieve an ORP of $280 \mathrm{mV}$.

Table 12 - pH 2 Basin 43 Groundwater/sodium chromate solutions titrated to $270 \mathrm{mV}$ - Trial \#1

\begin{tabular}{|c|c|c|c|c|c|}
\hline Color of solution & $\begin{array}{c}0.5 \mathrm{M} \mathrm{NaS} \mathrm{O}_{5} \\
(T o t a l ~ \mathrm{~mL})\end{array}$ & $\begin{array}{c}\mathrm{ORP} \\
(\mathrm{mV})\end{array}$ & $\mathrm{pH}$ & $\begin{array}{c}\text { aliquots } \\
\text { taken }\end{array}$ & $\begin{array}{c}\mathrm{HACH} \mathrm{Cr}(\mathrm{VI}) \\
\text { reading } \\
(\mathrm{ppm})\end{array}$ \\
\hline milky yellow & 0.0 & 657 & 2.06 & $\mathrm{~N} / \mathrm{A}$ & 110 \\
\hline yellow & 2.0 & 655 & 2.06 & N/A & N/A \\
\hline yellow & 6.0 & 646 & 2.38 & N/A & N/A \\
\hline yellow & 8.0 & 635 & 2.69 & N/A & N/A \\
\hline yellow & 10.0 & 585 & 3.86 & N/A & N/A \\
\hline yellow & 12.0 & 556 & 4.67 & N/A & N/A \\
\hline yellow & 14.0 & 539 & 5.00 & N/A & N/A \\
\hline yellow & 16.0 & 523 & 5.28 & N/A & N/A \\
\hline yellow & 18.0 & 513 & 5.47 & N/A & N/A \\
\hline yellow & 20.0 & 503 & 5.64 & N/A & N/A \\
\hline yellow & 22.0 & 488 & 5.89 & N/A & N/A \\
\hline Conc. acid addition & $700 \mu$ & 652 & 2.06 & N/A & N/A \\
\hline
\end{tabular}


RPP-RPT-34083, Rev. 0

Reduction from Chrome (VI) to Chrome (III)

Laboratory Report

\begin{tabular}{|c|c|c|c|c|c|}
\hline yellow & 24.0 & 653 & 2.13 & N/A & N/A \\
\hline yellow & 26.0 & 651 & 2.24 & N/A & N/A \\
\hline toothpaste pale blue & 31.0 & 349 & 2.68 & 1 st & $<0.01$ \\
\hline pale blue & 36.0 & 302 & 2.93 & N/A & N/A \\
\hline pale blue & 41.0 & 270 & 3.25 & 2 nd & N/A \\
\hline
\end{tabular}

The solution was then titrated to a $\mathrm{pH}$ of 10.5 or greater with $10 \underline{\mathrm{N}} \mathrm{NaOH}$. The results are provided in Table 13.

Table 13- $\mathrm{pH} 2$ reduced Basin 43 chrome solution titrated to $\mathrm{pH} 10.9$ Trial \#1

\begin{tabular}{|c|c|c|}
\hline $\begin{array}{c}10 \mathrm{~N} \mathrm{NaOH} \\
\text { total } \mathrm{mL})\end{array}$ & $\mathrm{pH}$ & Color Change \\
\hline 0.0 & 2.27 & $\mathrm{~N} / \mathrm{A}$ \\
\hline 0.5 & 2.30 & $\mathrm{~N} / \mathrm{A}$ \\
\hline 1.0 & 2.37 & $\mathrm{~N} / \mathrm{A}$ \\
\hline 1.5 & 2.45 & $\mathrm{~N} / \mathrm{A}$ \\
\hline 2.0 & 2.55 & $\mathrm{~N} / \mathrm{A}$ \\
\hline 2.5 & 2.69 & $\mathrm{~N} / \mathrm{A}$ \\
\hline 3.0 & 2.88 & $\mathrm{~N} / \mathrm{A}$ \\
\hline 3.5 & 3.22 & $\mathrm{~N} / \mathrm{A}$ \\
\hline 4.0 & 4.65 & $\mathrm{~N} / \mathrm{A}$ \\
\hline 4.5 & 6.54 & $\mathrm{~N} / \mathrm{A}$ \\
\hline 5.0 & 9.81 & Cloudy blue color \\
\hline 5.1 & 10.78 & N/A \\
\hline
\end{tabular}

For Case 1, Trial \#2, a working solution of the $\mathrm{pH} 2$ Basin 43/sodium chromate mixture was prepared. The solution had an initial $\mathrm{pH}$ of 8.09. It was adjusted to $\mathrm{pH} 1.99$ with an addition of $0.250 \mathrm{~mL}$ of concentrated $92 \%$ sulfuric acid. The corresponding ORP was $603 \mathrm{mV}$. The mixture was then titrated with sodium metabisulfite to attain an ORP of at least $300 \mathrm{mV}$ to provide the most reduction of chrome. The actual amounts used for this experiment are provided in Table 14. During the titration with sodium metabisulfite, the $\mathrm{pH}$ was adjusted with concentrated sulfuric acid to keep it within the 2.0 range unlike what was done in Trial \#1 above. This allowed for the addition of less sodium metabisulfite to the solution to achieve an ORP at about $280 \mathrm{mV}$. 
Table 14- $\mathrm{pH} 2$ Basin 43 Groundwater/sodium chromate solutions titrated to $270 \mathrm{mV}$ - Trial \#2

\begin{tabular}{|c|c|c|c|c|c|}
\hline Color of solution & $\begin{array}{c}0.5 \mathrm{M} \mathrm{NaS}_{2} \mathrm{O}_{5} \\
\text { (Total } \mathrm{mL} \text { ) }\end{array}$ & $\begin{array}{l}\text { ORP } \\
(\mathrm{mV})\end{array}$ & $\mathrm{pH}$ & $\begin{array}{l}\text { aliquots } \\
\text { taken }\end{array}$ & $\begin{array}{l}\mathrm{HACH} \mathrm{Cr}(\mathrm{VI}) \\
\text { reading }(\mathrm{ppm})\end{array}$ \\
\hline milky yellow & 0.0 & 603 & 1.99 & $1^{\mathrm{st} t *}$ & 110 \\
\hline yellow & 2.0 & 580 & 2.14 & N/A & N/A \\
\hline hint of blue & 4.0 & 430 & 2.5 & $N / A$ & N/A \\
\hline conc. acid addition & $100 \mu L$ & 553 & 2.03 & N/A & 10 \\
\hline lime & 6.0 & 374 & 2.21 & N/A & N/A \\
\hline conc. acid addition & $40 \mu L$ & 366 & 2.04 & $N / A$ & N/A \\
\hline blue green & 8.0 & 322 & 2.07 & N/A & N/A \\
\hline light blue & 10.0 & 307 & 2.10 & N/A & $<0.01$ \\
\hline light blue & 12.0 & 304 & 2.14 & N/A & $\mathrm{N} / \mathrm{A}$ \\
\hline conc. acid addition & $20 \mu$ & 302 & 2.06 & $N / A$ & N/A \\
\hline light blue & 14 & 297 & 2.10 & $N / A$ & N/A \\
\hline light blue & 16 & 292 & 2.13 & N/A & N/A \\
\hline conc. acid addition & $20 \mu$ & 294 & 2.06 & $N / A$ & N/A \\
\hline Added $700 \mathrm{~mL}$ of concentrated sulfuric & 18.0 & 291 & 2.10 & N/A & N/A \\
\hline light blue & 20.0 & 289 & 2.13 & N/A & N/A \\
\hline conc. acid addition & $20 \omega^{\prime}$ & 290 & 2.07 & $N / A$ & N/A \\
\hline toothpaste pale blue & 22.0 & 288 & 2.12 & $2^{n d_{* \hbar}}$ & BDL \\
\hline conc. acid addition & $20 \mu$ & 290 & 2.06 & N/A & N/A \\
\hline pale blue & 24.0 & 287 & 2.09 & N/A & N/A \\
\hline pale blue & 26.0 & 285 & 2.12 & N/A & N/A \\
\hline pale blue & 28.0 & 283 & 215 & N/A & N/A \\
\hline pale blue & 30.0 & 280 & 2.18 & $3^{r d_{t \hbar}}$ & BDL \\
\hline
\end{tabular}

${ }^{* *}$ Aliquots were taken for Cr6+ analysis using Ion Chromatography

\section{BDL $=$ Below Detection Limit}

The solution was then titrated to a $\mathrm{pH}$ of 10.5 or greater with $10 \underline{\mathrm{N}} \mathrm{NaOH}$. The results are provided in Table 15. A large volume of sodium hydroxide was necessary to adjust the $\mathrm{pH}$ to 10.5 . At the end of the titration, samples were removed for drying at $180^{\circ} \mathrm{C}$ and TCLP preparation for the analysis of Total Chrome. 
Table 15- $\mathrm{pH} 2$ reduced Basin 43 chrome solution titrated to $\mathrm{pH} 11.06$ Trial \#2

\begin{tabular}{|c|c|}
\hline $\begin{array}{c}10 \mathrm{~N} \mathrm{NaOH} \\
\text { (total } \mathrm{mL} \text { ) }\end{array}$ & $\mathrm{pH}$ \\
\hline 0 & 2.22 \\
\hline 5 & 8.95 \\
\hline 10 & 9.25 \\
\hline 15 & 9.32 \\
\hline 20 & 9.35 \\
\hline 25 & 9.37 \\
\hline 30 & 9.37 \\
\hline 35 & 9.4 \\
\hline 40 & 9.42 \\
\hline 45 & 9.48 \\
\hline 50 & 9.51 \\
\hline 55 & 9.56 \\
\hline 60 & 9.6 \\
\hline 65 & 9.65 \\
\hline 70 & 9.73 \\
\hline 75 & 9.81 \\
\hline 80 & $9.10^{\star}$ \\
\hline 85 & $11.06^{\star}$ \\
\hline
\end{tabular}

**A sample of this final batch was put aside and dried for total $\mathrm{Cr}$ and $\mathrm{Cr}^{6+}$ analysis.

For Case 1, Trial \#3, a working solution of the $\mathrm{pH} 2$ Basin 43/sodium chromate mixture was prepared. The solution had an initial $\mathrm{pH}$ of 7.45 . It was adjusted to $\mathrm{pH} 1.92$ with an addition of $0.2 \mathrm{~mL}$ of concentrated $92 \%$ sulfuric acid. The corresponding ORP was $609 \mathrm{mV}$. The mixture was then titrated with sodium metabisulfite to attain an ORP of at least $300 \mathrm{mV}$ to provide the most reduction of chrome. The actual amounts used for this experiment are provided in Table 16. During the titration with sodium metabisulfite, the $\mathrm{pH}$ was adjusted with concentrated sulfuric acid to keep it within the 2.0 range as was done with the Trial \#2.

Table 16- pH 2 Basin 43 Groundwater/sodium chromate solutions titrated to $270 \mathrm{mV}$ - Trial \#3

\begin{tabular}{|c|c|c|c|}
\hline Color of solution & $\begin{array}{c}0.5 \mathrm{M} \mathrm{NaS} \\
(\mathrm{Total} \mathrm{mL})\end{array}$ & $\begin{array}{c}\mathrm{ORP} \\
(\mathrm{mV})\end{array}$ & $\mathrm{pH}$ \\
\hline Yellow & 0.0 & N/A & N/A \\
\hline yellow & 1.0 & N/A & N/A \\
\hline conc. acid addition & $50 \mu L$ & 390 & 2.03 \\
\hline yellow & 2.0 & N/A & N/A \\
\hline conc. acid addition & $50 \mu L$ & 415 & 1.95 \\
\hline
\end{tabular}


RPP-RPT-34083, Rev. 0

Reduction from Chrome (VI) to Chrome (III)

Laboratory Report

\begin{tabular}{|c|c|c|c|}
\hline hint of blue & 3.0 & 347 & 2.05 \\
\hline lime & 4.0 & 341 & 2.08 \\
\hline lime & 5.0 & 337 & 2.1 \\
\hline lime & 10.0 & 326 & 2.22 \\
\hline lime & 15.0 & 320 & 2.28 \\
\hline lime & 20.0 & N/A & N/A \\
\hline conc. acid addition & $20 \mu L$ & 316 & 2.03 \\
\hline lime & 25.0 & N/A & N/A \\
\hline conc. acid addition & $20 \mu L$ & 319 & 2.07 \\
\hline lime & 30.0 & N/A & N/A \\
\hline conc. acid addition & $20 \mu L$ & 317 & 2.07 \\
\hline lime & 35.0 & N/A & N/A \\
\hline conc. acid addition & $60 \mu L$ & 316 & 2.04 \\
\hline lime & 40.0 & N/A & N/A \\
\hline conc. acid addition & $20 \mu L$ & 314 & 2.07 \\
\hline blue green & 45.0 & 311 & 2.11 \\
\hline light blue & 50.0 & 309 & 2.14 \\
\hline light blue & 55.0 & 307 & 2.18 \\
\hline light blue & 60 & 305 & 2.22 \\
\hline light blue & 70 & 302 & 2.29 \\
\hline light blue & 80.0 & 299 & 2.34 \\
\hline light blue & 130.0 & 283 & 2.58 \\
\hline
\end{tabular}

The solution was then titrated to a $\mathrm{pH}$ greater than 10.5 with $10 \underline{\mathrm{N}} \mathrm{NaOH}$. The results are provided in Table 17. A large volume of sodium hydroxide was necessary to adjust the $\mathrm{pH}$ to 10.5. At the end of the titration, two samples were removed for drying at $180^{\circ} \mathrm{C}$ and TCLP preparation for the analysis of Total Chrome.

Table 17- $\mathrm{pH} 2$ reduced Basin 43 chrome solution titrated to $\mathrm{pH} 11.5-$ Trial \#3

\begin{tabular}{|c|c|}
\hline $\begin{array}{c}10 \mathrm{~N} \\
\text { (total } \mathrm{NL} \text { ) }\end{array}$ & $\mathrm{pH}$ \\
\hline 0.0 & 2.59 \\
\hline 10.0 & 5.4 \\
\hline 20.0 & 8.88 \\
\hline 330.0 & 9.08 \\
\hline 40.0 & 9.12 \\
\hline 50.0 & 9.16 \\
\hline 60.0 & 9.21 \\
\hline 70.0 & 9.31 \\
\hline 80.0 & 9.41 \\
\hline
\end{tabular}


RPP-RPT-34083, Rev. 0

Reduction from Chrome (VI) to Chrome (III)

Laboratory Report

\begin{tabular}{|c|c|}
\hline 90.0 & 9.55 \\
\hline 100.0 & 9.8 \\
\hline 109.0 & $10.6^{\text {}}$ \\
\hline 118.0 & $11.5^{\text {t* }}$ \\
\hline
\end{tabular}

${ }^{* *} \mathrm{~A}$ sample of this final batch was put aside and dried for total $\mathrm{Cr}$ and $\mathrm{Cr}^{6+}$ analysis.

\subsection{Phase II, Case I Experimental Results}

After completion of Phase II, all of the data regarding TCLP analysis for total $\mathrm{Cr}$ and $\mathrm{Cr}^{6+}$ were compiled and reviewed to determine success of using Basin 43 Groundwater as a matrix. Total chrome analysis was performed using a Perkin-Elmer ICP/MS. The hexavalent chrome was quantified using ion chromatography. The TCLP results for the Trial \#2 and 3 mixtures denoted by an asterisk (*) in Tables 15 and 17 are provided in Table 8.

Table 18- TCLP and $\mathrm{Cr}^{6}+$ results for $\mathrm{pH} 2$ Basin 43 reduced chrome experiments

\begin{tabular}{|c|c|c|c|c|c|}
\hline Trial \# & $\mathrm{pH}$ & $\begin{array}{c}\mathrm{ORP} \\
(\mathrm{mV})\end{array}$ & $\begin{array}{c}\mathrm{HACH} \\
(\mathrm{ppm})\end{array}$ & $\begin{array}{c}\mathrm{Cr}^{6+} \\
(\mathrm{ppm})\end{array}$ & $\begin{array}{c}\text { Total } \mathrm{Cr} \\
(\mathrm{ppm})\end{array}$ \\
\hline \multicolumn{6}{|c|}{ Prior and during titration with 0.5M Sodium Metabisulfite } \\
\hline 2-Aliquot \#1 & 1.99 & 603 & 110 & 105.1 & $\mathrm{~N} / \mathrm{A}$ \\
\hline 2-Aliquot \#2 & 2.12 & 288 & $\mathrm{BDL}$ & $\mathrm{BDL}$ & $\mathrm{N} / \mathrm{A}$ \\
\hline 2-Aliquot \#3 & 2.18 & 280 & $\mathrm{BDL}$ & $\mathrm{BDL}$ & $\mathrm{N} / \mathrm{A}$ \\
\hline \multicolumn{7}{|c|}{ After titration with 10N Sodium Hydroxide } \\
\hline 2-Aliquot \#1 & 9.1 & $\mathrm{~N} / \mathrm{A}$ & $\mathrm{N} / \mathrm{A}$ & $\mathrm{N} / \mathrm{A}$ & 17.65 \\
\hline 2-Aliquot \#2 & 11.06 & $\mathrm{~N} / \mathrm{A}$ & $\mathrm{N} / \mathrm{A}$ & $\mathrm{N} / \mathrm{A}$ & 0.08494 \\
\hline 3-Aliquot \#1 & 10.6 & $\mathrm{~N} / \mathrm{A}$ & $\mathrm{N} / \mathrm{A}$ & $\mathrm{N} / \mathrm{A}$ & 2.79 \\
\hline 3-Aliquot \#2 & 11.5 & $\mathrm{~N} / \mathrm{A}$ & $\mathrm{N} / \mathrm{A}$ & $\mathrm{N} / \mathrm{A}$ & 3.4 \\
\hline
\end{tabular}

As shown in Table 18, the $\mathrm{Cr}^{6+}$ content in the Basin 43 groundwater was effectively reduced from $100 \mathrm{ppm}$ with the use of sodium metabisulfite.

\subsection{Summary}

Based on all of the data regarding the hexavalent chrome and trivalent chrome concentrations, it appears that the addition of sodium metabisulfite is a useful means of reducing chrome in sodium sulfate and Basin 43 waste waters at a $\mathrm{pH}$ of 2 . The concentration of $\mathrm{Cr}^{6+}$ was drastically reduced with this method, which promotes the success of immobilizing the chrome in the environment, aiding in ERDF's land disposal requirements. 